\title{
Perancangan Sistem Informasi Persediaan Barang menggunakan metode RUP (Studi Kasus PT Medical Device Indonesia)
}

\author{
Noer Hikmah ${ }^{1}$, Rendi Simon Lesmana ${ }^{2}$, Leliyanah $^{3}$,Dwi yuni Utami ${ }^{4}$ \\ ${ }^{1,2}$ Program Studi Sistem Informasi, Fakultas Teknik dan Informatika, Universitas Bina Sarana Informatika, \\ Jl. Kramat Raya No.98, Jakarta Pusat, DKI Jakarta 10450, Indonesia \\ ${ }^{3}$ Program Studi Teknologi Informasi, Fakultas Teknik dan Informatika, Universitas Bina Sarana Informatika, \\ Jl. Kramat Raya No.98, Jakarta Pusat, DKI Jakarta 10450, Indonesia \\ ${ }^{4}$ Program Studi Teknologi Komputer, Fakultas Teknik dan Informatika, Universitas Bina Sarana Informatika \\ Jl. Kramat Raya No.98, Jakarta Pusat, DKI Jakarta 10450, Indonesia \\ e-mail: $\underline{1}$ noer.nhh@bsi.ac.id, ${ }^{2}$ rendi10bkz@gmail.com, ${ }^{3}$ eliyanah.1lh@bsi.ac.id, ${ }^{4}$ dwi.dyu@bsi.ac.id
}

\begin{tabular}{l|l|l|l} 
Artikel Info : Diterima : 19-01-2021 & Direvisi : 22-01-2021 & Disetujui : 25-01-2021
\end{tabular}

\begin{abstract}
Abstrak - PT. Medical Device Indonesia merupakan perusahaan yang bergerak dibidang Distributor Buku dan Alat Kesehatan. Dalam proses pengolahan data khususnya bagian persediaan barang menggunakan cara manual. Hal ini membuat owner dan karyawan PT. Medical Device Indonesia kewalahan dalam pengelolaan data, sehingga perlu adanya suatu sistem untuk mempermudah proses persediaan barang. Tujuan dari penelitian ini yaitu menganalisa serta merancang sebuah sistem informasi persediaan barang berbasis web sehingga data yang diperoleh lebih akurat dan meminimalisir kesalahan dalam pengolahan data. Metode yang digunakan dalam pengembangan sistem yaitu menggunakan metodologi RUP ( Rational Unified Process) serta melakukan observasi dan wawancara kepada pihak pihak yang terlibat. Untuk metode perancangan sistem menggunakan metode Object Oriented Analysis and Design dengan menggunakan UML seperti usecase diagram,activity diagram, sequence diagram. Hasil dari sistem user dapat manage produk dengan mudah, melakukan transaksi dengan lengkap dan mengolah laporan secara lengkap.
\end{abstract}

Kata Kunci : web, persediaan barang, RUP

\begin{abstract}
PT Medical Device Indonesia is a company in the distribution of books and medical devices. In the data processing specially the inventory section it used manual way. It made owner and employees of PT. Medical Device Indonesia become overshelmed in data management, so there is a need for a system to simple the inventory process. The study aims to analyze and design a web based inventory information system, so that the data is more accurate and minimizes errors in data processing. The method used in system development is using the RUP (Rational Unified Process) methodology as making observations and interviews with the parties involved. For the system design method using the Object Oriented Analysis and Design method using UML such as usecase diagrams, activity diagrams, sequence diagrams. The results of this system are the users are able to manage product easily, perfoming complete transaction and process the reports completely.
\end{abstract}

Keywords : website, inventory, RUP

\section{PENDAHULUAN}

Aneka ragam jenis transaksi yang semakin banyak dapat menyebabkan timbul beberapa masalah dan kadang kala sering terjadi kesalahan dalam proses persediaan barang, hal ini disebabkan karena untuk mengetahui stok barang masih menggunakan sistem manual.

Persediaan adalah merupakan aset paling utama dan penting dengan menyumbangkan sekitar lima puluh persen dari jumlah modal yang dinvestasikan sehingga persediaan barang merupakan yang terpenting.(Jayanti,2015)

Sedangkan menurut (Rufaidah \& Fatakh, 2018) Persediaan juga dapat diartikan sebagai bahan atau barang yang disimpan yang akan digunakan untuk memenuhi tujuan tertentu.

This work is licensed under a Creative Commons Attribution-ShareAlike 4.0 International License. 
Hal ini membuat pemeriksaan data menjadi sebuah informasi yang diperlukan, pada bagian-bagian terkait tidak berjalan dengan baik, Jika perusahaan tidak tepat dalam menghitung stok barang, maka tidak tutup kemungkinan perusahaan akan kehilangan peluang keuntungan dari permohonan pasar. Jangan sampai pada saat teerdapat permintaan dari konsumen, perusahaan tidak dapat menyediakan dikarenakan kesalahan dalam perhitungan stok. Hal tersebut tentu juga akan berpengaruh pada tingkat kepercayaan konsumen. Masalah-masalah tersebut diatas disebabkan sistem persediaan barang belum tertata dengan baik. Sehingga memastikan perusahaan untuk mengerjakan sistem persediaan barang yang mampu mengolah data secara tepat, akurat dan otomatis, dan dapat menyimpan serta dapat mempertunjukan data transaksi yang berhubunga dengan sistem persediaan barang maka informasi yang didapat akan tertata dengan baik. Pada masalah tersebut diatas diperlukan sebuah sistem informasi pengolahan pada persediaan barang. Informasi barang yang ada di dalam gudang sangatlah penting pada suatu perusahaan terutama dalam menentukan aktifitas perusahaan baik transaksi pembelian atau penjualan. Dimana informasi mengenai stok minimum dan arus keluar masuk barang akan mempengaruhi persediaan.

Sistem Informasi Perseediaan barang merupakan sistem yang dapat digunakan untuk meng-input data persediaan barang ke dalam database agar mengurangi kesalahan dalam input, output dan pembuatan laporan dari data yang diinginkan. .(Setiyanto et al., 2019)

Jika memiliki sistem persediaan barang yang baik, maka bagian-bagian terkait akan dapat memperkirakan kebutuhan perusahaan saat itu. Dengan mengetahui Banyaknya stok yang ada atau jumlah barang yang habis maka akan berpengaruh pada biaya yang diperlukan untuk mengawasi stok barang agar tetap ada. Jika memiliki kesalahan pada proses perhitungan, maka perusahaan bisa mengalami kerugian di karenakan harus mengeluarkan biaya lebih yang tidak diinginkan. Oleh karena itu, diharapkan dengan adanya sistem informasi ini, pengelolaan persediaan barang menjadi lebih efektif dan efisien, pencarian informasi persediaan/stok dan laporan juga lebih akurat dan cepat.

Tahapan dalam merancang sistem informasi persediaan barang yaitu dengan metode RUP(Rational Unified Process). Merupan metode Pengembangan perangkat lunak yang dikombinasikan oleh rational software corporation dengan menggunakan UML(Unified modeling language) pada pengembangan perangkat lunak. RUP terdiri dari empat fase pengembangan sistem yaitu fase inception, fase elaboration, fase construction dan fase transition.

Rational Unified Process (RUP) merupakan suatu pendekatan untuk siklus pengembangan perangkat lunak dengan menggunakan konsep object oriented, dimana aktifitas metode tersebut berfokus pada pengembangan model dengan menggunakan Unified Model Language (UML)

Aktifitas diperusahaan saat ini banyak menggunakan sistem yang terkomputerisasi untuk memudahkan karyawan dalam mengelolah data. Banyak perusahaan yang bergerak dibidang perdagangan menggunakan aplikasi untuk meningkatkan produktifitas, baik dalam memperoleh data, mengolah data dan menggunakan data tersebut khususnya untuk kepentingan internal perusahaan.

suatu sistem akan dapat berjalan dengan maksimal serta memenuhi kebutuhan pengguna sistem, maka perlu dibuat perekayasaan perangkat lunak yang bagus. Salah satunya tahapan rekayasa perangkat lunak adalah yaitu tahap perancangan sistem. Berdasarkan hal tersebut diatas, maka dalam penelitian ini dibuat sebuah perancangan sistem yang baik dan dengan adanya perancangan ini diharapkan dapat dijadikan sebagai panduan dalam pembangunan atau implementasi sistem informasi persediaan barang.

\section{METODE PENELITIAN}

Dengan memenuhi bisnis process maka akan menghasilkan sebuah sistem informasi yang memadai sehingga diperlukan sebuah metode pengembangan perangkat lunak( Susilowati,2017)

Menggunakan metodologi RUP (Rational Unified Process) adalah pendekatan pengembangan perangkat lunak yang dilakukan berulang-ulang (iterative), fokus pada arsitektur (architecture-centric), lebih diarahkan berdasarkan penggunaan kasus (use case driven) (AS \& Shalahuddin, 2011). Fase-fase dalam Metodologi RUP terdiri dari:

1. Inception (permulaan)

Fase ini digunakan untuk meninjau, meningkatkan dan membuat model proses bisnis dan menggambarkan sistem apa yang harus dilakukan.

2. Elaboration (perluasan/perencanaan)

Tahap ini memfokuskan pada analisa, desain sistem dan penerapannya. Apakah dengan perencanaan desain sistem tersebuat, perangkat atau arsitektur sistem dapat mendukung atau tidak.

3. Construction (konstruksi)

Didalam tahap ini adanya testing atau pengujian sistem yang berfokus pada implementasi perangkat lunak pada kode program.

4. Transition (Transisi)

Tahap ini mengimplemetasikan dari membuat apa yang sudah dimodelkan menjadi suatu produk jadi yaitu berupa rancangan sistem informasi. Dan pada tahap ini, terdapat training user, dan pemeliharaan serta pengujian sistem. 


\section{HASIL DAN PEMBAHASAN}

\subsection{Prosedur Sistem Berjalan}

Pada tahap ini, penulis menggambarkan analisa permasalahan atau sistem berjalan yanga ada dalam sistem inforamsi persediaan barang pada PT. Medical Device Indonesia. Prosedur sistem berjalan merupakan sebuah tahapan suatu kegiatan yang dibuat oleh perusahaan dalam memproses suatu aktifitas atau rutinitas dari perusahaan tersebut.

Pada prosedur sistem berjalan penulis memfokuskan dalam permasalahan keluar masuknya barang yang dialami oleh Staff Gudang yang menjadi landasan rancangan sistem persediaan barang berbasis web ini. Prosedur sistem berjalan bertujuan untuk mengetahui bagaimana sistem lama berjalan juga mengetahui kekurangan dari sistem lama tersebut. Prosedur Pendataan manual keluar masuknya barang serta perhitungan jumlah barang di deskripsikan sebagai berikut.

a. Prosedur Masuknya Produk :

1. Staff gudang melaporkan via email terkait stok barang yang telah habis ke jajaran staff terkait.

2. Selanjutnya staff terkait (marketing manajer) membuat list Pre- order untuk memesan produk yang telah habis dan lalu konfirmasi ke produk manajer dan direktur melalui email .

3. List Pre-order telah dikonfirmasi selanjutnya marketing manajer memberikan list Pre-order kepada akutansi manajer untuk membuat melakukan pembayaran pemesanan produk ke supplier

4. Akutansi manajer melakukan pembayaran produk yang akan di order dan mengkonfirmasi ke Supplier bahwa pembayaran sudah dilakukan.

5. Supplier Konfirmasi pembayaran telah diterima lalu mengkonfirmasi jadwal pengiriman produk ke akutansi manajer melalui email.

6. Akutansi manajer mengkonfirmasi kepada staff gudang bahwa barang dari supplier sedang menuju ke gudang.

7. Produk datang ke gudang dan diterima dan dihitung kembali secara tertulis.

b. Proses Keluarnya Produk :

1. Staff sales memberikan data produk yang harus dikirim ke staff gudang.

2. Lalu Staff gudang membuatkan surat jalan untuk keluarnya produk lalu menyiapkan produk dan mempackingnya untuk segera diserahkan ke staff logistik.

3. Barang keluar gudang, didata secara tertulis berdasarkan surat jalan yang dibuat, lalu diberikan ke staff logistik untuk melakukan pengiriman ke alamat pelanggan.

c. Prosedur Pelaporan Produk :

1. Staff Gudang menghitung selisih produk yang masuk dan keluar yang telah didata secara tertulis lalu dimasukan ke excel dengan menambah atau mengurangi data stock berjalan sesuai dengan aktivitas yang dilakukan dengan perhitungan secara manual.

2. Lalu excel dikirim via email kepada jajaran staff terkait untuk mendapatkan informasi stock terupdate bila dibutuhkan.

\subsection{Prosedur Sistem Usulan}

Langkah pertama dalam membuat suatu sistem adalah perancangan dari sistem tersebut. Perancangan adalah proses pengembangan spesifikasi baru berdasarkan referensi hasil analisis suatu sistem (Nugroho, 2016).

Sistem merupakan sekumpulan unsur atau elemen yang saling berhubungan serta saling mempengaruhi didalam melakukan suatu aktivitas bersama untuk mencapai suatu tujuan (Sidh, 2013).

informasi adalah data yang telah diproses atau diolah dengan suatu cara tertentu atau metode tertentu atau rumus tertentu sehingga menghasilkan suatu arti (Munawaroh, 2006)..

Sistem informasi merupakan gabungan dari manusia(orang), perangkat keras(hardware), perangkat lunak(software), jaringan komunikasi serta sumber daya terdiri dari data yang mengumpulkan, membarui,meluaskan informasi dalam sebuah organisasi (firman et al.,2016)

Perancangan sistem merupakan langkah terpenting didalam menentukan sketsa perangkat yang akan dibuat ketika proses pengembangan sistem dalam melaksanakan sebuah proyek pembuatan perangkat lunak. Perangkat lunak yang baik dan sesuai dengan kebutuhan pengguna sangat berpengaruh pada saat melakukan tahap analisa kebutuhan. Berikut kebutuhan sistem yang diusulkan dalam perancangan sistem persediaan barang pada PT. Medical Device Indonesia.

\section{Kebutuhan Pengguna}

\section{Staff Gudang}

a. Staff Gudang dapat melakukan login 
b. Staff Gudang dapat menginput produk

c. Staff Gudang dapat mengupdate produk

d. Staff Gudang dapat menghapus produk

e. Staff Gudang dapat mengganti password

f. Staff Gudang dapat melihat laporan keluarnya produk

g. Staff Gudang dapat melihat laporan stok berjalan

h. Staff Gudang dapat mengunduh laporan keluar masuknya produk

\section{Jajaran Staff}
a. Jajaran Staff dapat melakukan login
b. Jajaran Staff dapat mengganti password
c. Jajaran Staff dapat melihat laporan keluarnya produk
d. Jajaran Staff dapat melihat masuknya produk
e. Jajaran Staff dapat mengunduh laporan keluar masuknya produk

\section{Kebutuhan Sistem}

a. Sistem dapat membedakan hak akses dari setiap pengguna.

b. Sistem dapat memberikan informasi apabila pengguna mengalami kesalahan dalam penginputan data.

c. Pengguna wajib memliliki akun untuk mengakses sistem masing masing akun memiliki hak akses yang berbeda.

d. Sistem mempunyai tampilan yang sederhana yang sangat user friendly.

\subsection{Model Pengembangan Sistem}

UML merupakan salah satu alat bantu yang sangat teruji dalam bidang pengembangan sistem yang berorientasi objek. dikarenakan UML menyajikan Bahasa pemodelan visual yang membolehkan pengembang sistem untuk membuat cetak biru atas visi yang telah dibuat dalam bentuk yang baku (Padeli et al., 2008).

\section{Fase Inception}

Pada fase ini yaitu dilakukan pendefinisian kebutuhan dari sistem yang dikembangkan. Pada penelitian ini menggunakan pemodelan usecase. Adapun gambar usecase sebagai berikut:

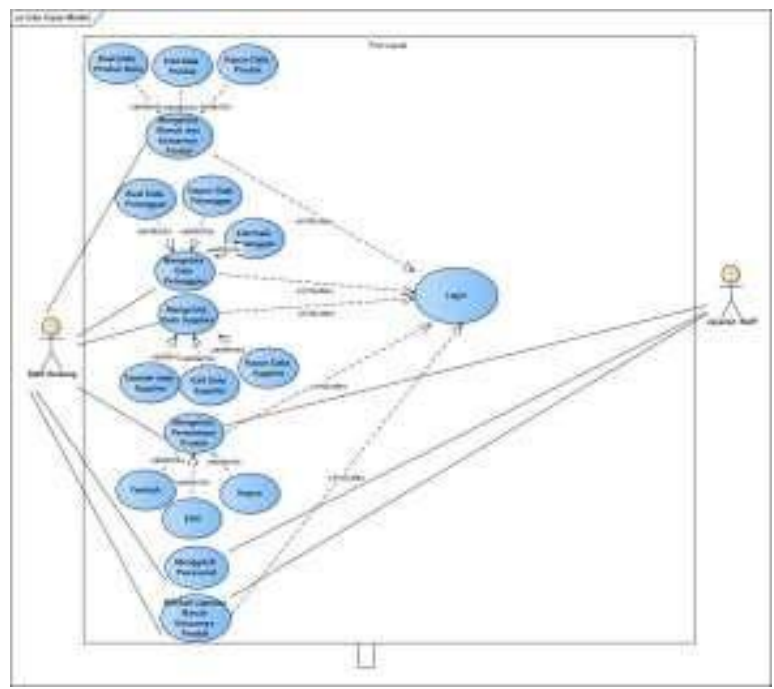

Gambar 1. Use Case Diagram Fish Level

\section{Fase Eloboration}

Pada tahap ini berfokus pada perencanaan arsitektur sistem dengan mengusulkan rancangan prosedur baru yang akan mulai diterapkan pada sebagian tahapan pengelolaan data dengan memanfaatkan sebuah aplikasi yang dirancang khusus untuk memenuhi kebutuhan pihak terkait dalam mengelola perusahaan. Dimana pada penelitina ini menggunakan activity diagram. 


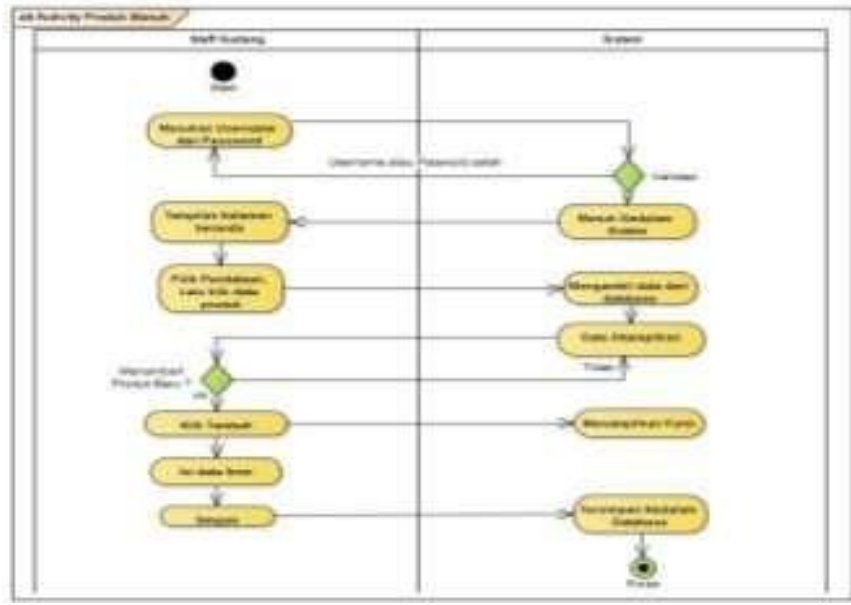

Gambar 3. Diagram Activity Produk Masuk

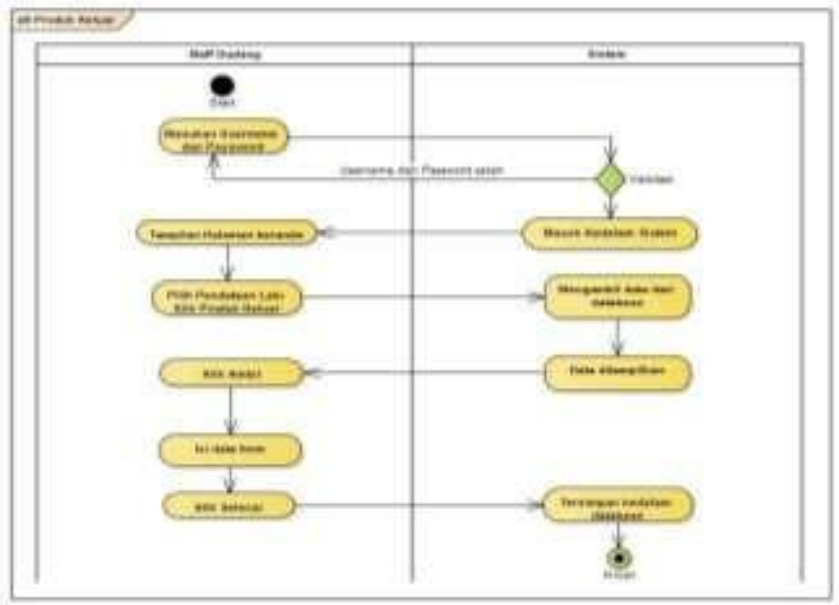

Gambar 4. Diagram Activity Produk Keluar

\section{Fase Constructions}

Spesifikasi sistem merupakan kebutuhan standar untuk mengetahui sistem yang ada dan digunakan, sebagai dasar bagi rekayasa perangkat keras dan perangkat lunak sehingga menjadi gambaran fungsi dan kinerja dari sebuah sistem yang akan dibangun atau dikembangkan. Pada fase ini dibuat rancangan program berbasis web menggunakan metode Rational Unified Process (RUP).

1. Halaman Login

Pada halaman login adalah halaman untuk masuk ke halaman sesuai akun masing-masing user. Adapun tampilan halaman login dapat dilihat pada gambar berikut.

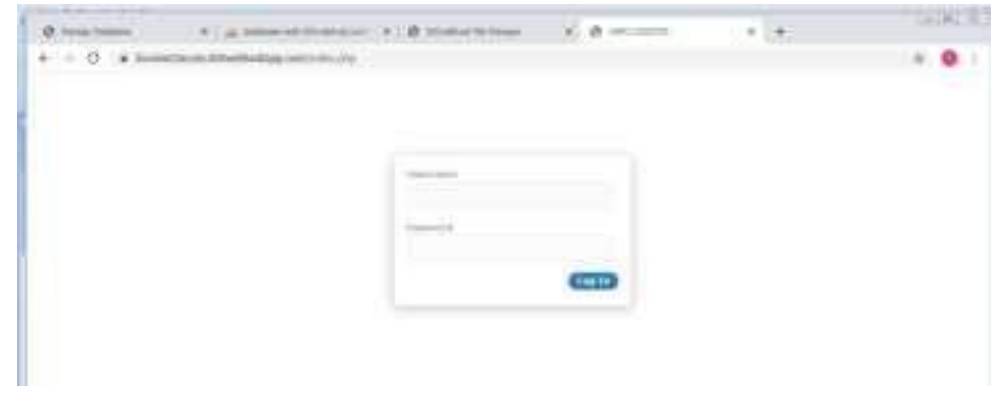

Gambar 5. Halaman Login 
2. Halaman Beranda (Halaman Utama)

Didalam halaman ini terdapat beberapa menu, diantaranya menu home, pendataan, informasi, laporan , konfigurasi dan logut. Dari masing-masing menu tersebut memiliki link yang berbeda, dan memiliki fungsi yang berbeda pula.

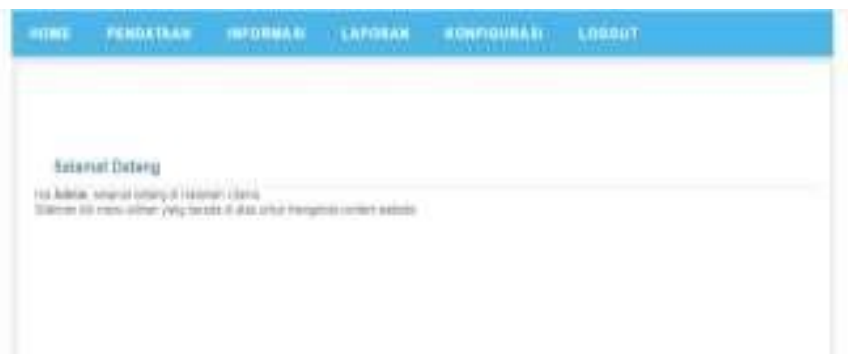

Gambar 6. Halaman Utama

3. Halaman Produk Masuk

Halaman ini dirancang dengan berbagai fitur yang dikhususkan untuk menambah data produk baru, cari produk, dan menghapus produk

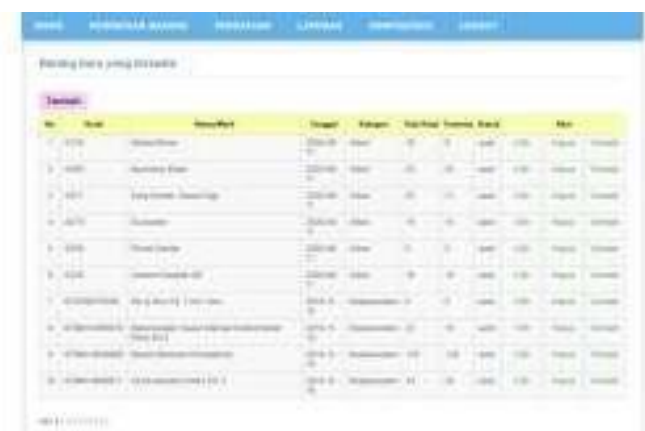

Gambar 7. Halaman Produk Masuk

4. Halaman Produk Keluar

Halaman ini berisi informasi secara keselurahan mengenai data barang keluar dari gudang serta dapat melakukan cari dan tambah.

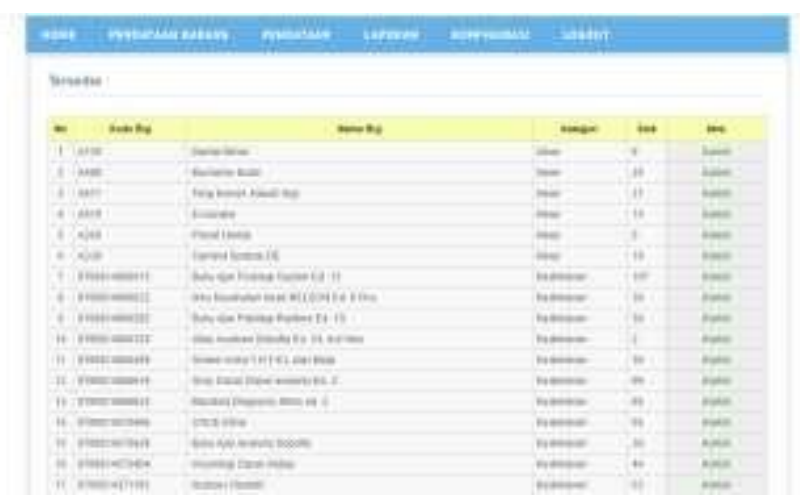

Gambar 8. Halaman Produk Keluar

5. Halaman Laporan Stok Produk

Halaman yang menginformasikan tentang keseluruhan data stok produk 


\begin{tabular}{|c|c|c|c|c|c|c|c|c|}
\hline \multicolumn{9}{|c|}{ LAPCRQN DATA GaQRNS } \\
\hline (a) & 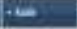 & $10=$ & ines & $10=$ & par & fane & $j=i$ & Finn \\
\hline$\varepsilon$ & a & Derter & $200=20$ & $4 \pi$ & $\pi$ & I & $\approx$ & beti \\
\hline e & $=$ & therestir & mosa & 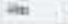 & n & in & is & bath \\
\hline n. & an & Defien intion & mans & An & $a$ & in & $\Rightarrow$ & hat \\
\hline$=$ & ax: & Dane & maso & at: & in & n & a & tath \\
\hline II & 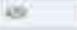 & nodiete & weres & Hes & 1 & 1 & $\Rightarrow$ & ten \\
\hline$\rightarrow$ & as & Inesima & $m>0$ & tan & $\pi$ & A & 4 & mon \\
\hline u & nanaw & 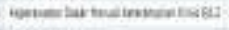 & mais & neones & Di & " & 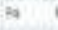 & lows \\
\hline ii & 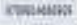 & sobseraven - & ankida & nenew & ivi & ui. & a & bati \\
\hline II & rusesun & 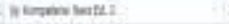 & molata & hesanen. & H & u & to & hat \\
\hline$=$ & rnotevent & hlomitres: & malas & hoonin: & s & s & $\approx$ & bath \\
\hline
\end{tabular}

Gambar 10. Halaman Laporan Stok Produk

6. Halaman Laporan Produk Keluar

Halaman yang dapat menampilkan laporan untuk mengetahui informasi detail terhadap produk yang keluar dari Gudang.

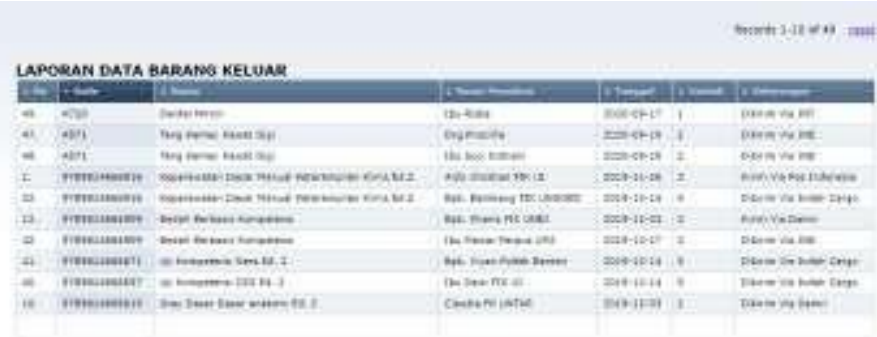

Gambar 11. Halaman Laporan Produk Keluar

7. Halaman Ganti Password

Didalam halaman ini, pihak admin atau user dapat mengganti password lama ke password baru

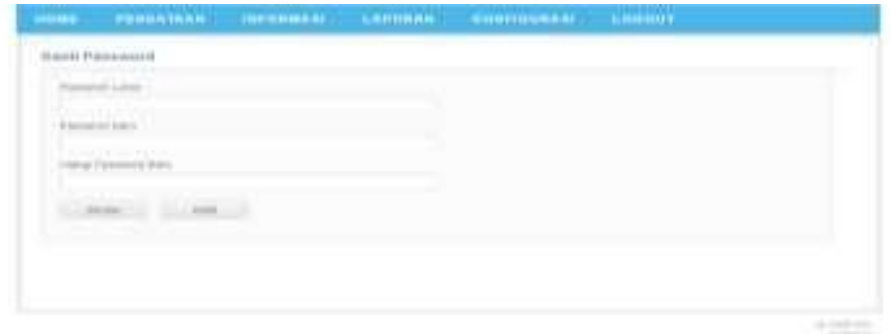

Gambar 12. Halaman Ganti Password

8. Halaman Supplier

Halaman ini dapat memberikan informasi secara rinci, pihak-pihak yang bekerja sama dengan perusahaan yakni data supplier. 


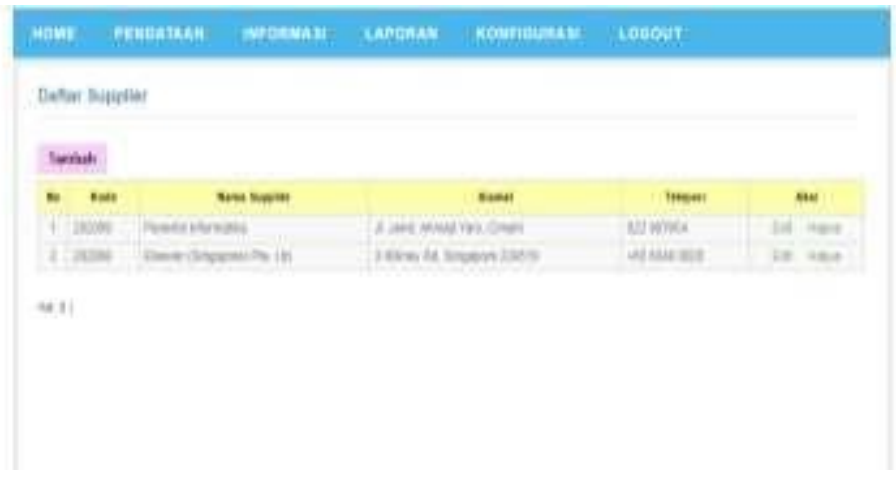

Gambar 13. Halaman Supplier

\section{KESIMPULAN}

Berdasarkan penelitian yang telah dilakukan, maka dapat ditarik kesimpulan, antara lain:

1. Dengan pembuatan sistem informasi ini dapat membantu meningkatkan efisiensi waktu dalam memberikan informasi ketersediaan stok barang yang ada digudang secara cepat dan akurat.

2. Dapat meningkatkan efisiensi waktu dalam pencatatan persediaan barang masuk dan keluar secara update dan realtime.

3. Dapat menyajikan informasi-informasi tentang persediaan barang sampai laporan PT Medical Device Indonesia yang dapat digunakan setiap saat dengan mudah.

4. Dengan pendekatan perancangan objek oriented dapat menghasilkan dokumen perancangan yang dapat membantu pengembang sistem dalam membangun sistem informasi persediaan barang.

5. Sistem informasi tersebut juga menjadikan pekerjaan dalam pengelolaan persedian stok barang menjadi lebih mudah. Data-data menjadi lebih aman daripada pencatatan dengan sistem manual di kertas-kertas yang bisa hilang kapan saja.

6. Adanya sistem informasi tersebut tidak menyebabkan barang yang berlebihan atau kekurangan, sehingga dapat membantu meminimalisir kerugian atas barang yang melewati batas tanggal kadaluarsa.

\section{REFERENSI}

AS, R., \& Shalahuddin, M. (2011). Modul Pembelajaran Rekayasa Perangkat Lunak. Modula.

Firman, A., Wowor, H. F., Najoan, X., Teknik, J., Fakultas, E., \& Unsrat, T. (2016). Sistem Informasi Perpustakaan Online Berbasis Web. E-Journal Teknik Elektro Dan Komputer, 5(2), 29-36.

Jayanti, N. K. D. A. (2015). Perancangan Sistem Informasi Persediaan Barang Menggunakan Model Reorder Point. EKSPLORA INFORMATIKA, 5(1), 85-96.

Munawaroh, S. (2006). Perancangan Sistem Informasi Persediaan Barang. Jurnal Teknologi Informasi DINAMIK, $X I(2), 124-133$.

Nugroho, F. E. (2016). Perancangan Sistem Informasi Penjualan Online Studi Kasus Tokoku. Simetris : Jurnal Teknik Mesin, Elektro Dan Ilmu Komputer, 7(2), 717. https://doi.org/10.24176/simet.v7i2.786

Nurfaizah, Sarmini, \& O. Novitasari. (2017). Implementasi Rational Unified Process Pada Sistem Informasi Simpan Pinjam Kelompok Perempuan, in CITISE, 126-129

Padeli, P., Henderi, H., \& Suyatno, S. (2008). Membangun (E-Procurement) Pengadaan Barang dan Jasa dengan Prinsip Good Corporate Governance dengan Visual UML. Creative Communication and Innovative Technology Journal, 2(1), 69-79.

Rufaidah, A., \& Fatakh, A. (2018). ANALISIS PENGENDALIAN PERSEDIAAN BAHAN BAKU DENGAN MENGGUNAKAN METODE ECONOMIC ORDER QUANTITY (EOQ) DI PT. X. Jurnal Penelitian Dan Pengabdian Kepada Masyarakat UNSIQ 4 (3) Tahun 2017, 1(2), 40-45. 


\section{Computer Science (CO-SCIENCE)}

Volume 1 No. 1 Januari 2021 | E-ISSN: 2774-9711

https://core.ac.uk/download/pdf/229505614.pdf

Setiyanto, R., Nurmaesah, N., \& Rahayu, N. S. A. (2019). Perancangan Sistem Informasi Persediaan Barang Studi Kasus di Vahncollections. Jurnal Sisfotek Global, 9(1), 137-142. https://shopee.co.id/vahncollections.

Sidh, R. (2013). PERANAN BRAINWARE DALAM SISTEM INFORMASI MANAJEMEN. Jurnal Computech \& Bisnis, 7(1), 19-29. https://doi.org/10.1021/jf60200a019

Susilowati, S. (2017). PERANCANGAN SISTEM INFORMASI PEMESANAN MAKAM BARU MENGGUNAKAN METODE RATIONAL UNIFIED PROCESS (Studi kasus pada Taman Pemakaman Umum Joglo Jakarta Barat). Jurnal Pilar Nusa Mandiri, 13(ISSN 1978-1946 \& E-ISSN 2527-6514), 9297. http://ejournal.nusamandiri.ac.id/ejurnal/index.php/pilar/article/view/342 